\title{
State of the environment and natural resources in Vietnam
}

\author{
Thực trạng môi trường và tài nguyên thiên nhiên ở Việt Nam
}

Editorial

Chu, Thi Thu Ha*

Institute of Ecology and Biological Resources, Vietnam Academy of Science and Technology, 18 Hoang Quoc Viet, Hanoi, Vietnam

\begin{abstract}
Vietnam is considered as one of the countries having rich resources from forest and sea, with a high average annual rainfall. However, in view of IWRA, water volume per capita annually in Vietnam is lower than the standard for nations having water resources at average level. Vietnam was recognized by the World Wildlife Fund (WWF) as having three out of more than 200 biological zones of the world. Flora and fauna in Vietnam are very rich and abundant, but due to indiscriminate exploitation, along with weak management, biodiversity levels are significantly reduced. This is also one of the causes of environmental pollution and degradation in Vietnam, besides the impacts from production activities, population migration from rural areas to urban areas, rapid urbanization, climate change and sea level rise, etc.
\end{abstract}

Việt Nam được coi là một trong nhũng quốc gia giàu nguồn tài nguyên tù rùng và biển, có luợng muxa trung bình hàng năm cao. Tuy nhiên, lương nước bình quân đầu người hàng năm ở Việt Nam thấp hơn so với tiêu chuẩn cho quốc gia có nguồn nước ở mức trung bình theo quan điểm của Hiệp hội nuớc quốc tế (IWRA). Việt Nam được Quỹ Quốc tế về Bảo vệ thiên nhiên (WWF) công nhận có 3 trong số hơn 200 vùng sinh thái toàn cầu. Hệ động thực vật ở Việt Nam rất phong phú, nhưng do vấn nạn khai thác bùa bãi, cùng với sự quản lý yếu kém, mức đa dạng sinh học đã bị giảm đáng kể. Đây cũng là một trong những nguyên nhân gây ô nhiếm và suy thoái môi truò̀ng ở Việt Nam, bên cạnh các tác động tù hoạt động sản xuất, di dân, đô thị hóa, biến đổi khí hậu và nước biển dâng, v.v...

Keywords: environment degradation, biological resources, water resources, climate change, sea level rise, greenhouse gas

\section{Introduction}

Along with the development of science and technology, perceptions and demands of human beings to live in a safe and high quality environment is of most concern by many countries. Vietnam's population ranks $14^{\text {th }}$ in the world, and it is one of the countries having highest population density (MONRE, 2010). Rapid population growth and rapid urbanization caused by the people moving from rural areas to urban areas make it difficult for the country to ensure the environmental quality and prevent, minimize the degradation of natural resources.

Vietnam is one of the countries having abundant natural resources with high potential of exploitation. However, due to weak management, low and backward technology, excessive exploitation of natural resources, the effects of climate change and sea level rise, as well as the limited awareness of the people in the environmental protection, the quality of the environment and natural resources declines significantly.

This paper aims to provide partly the situation of environment and natural resources in Vietnam with the expectation of attracting the researches and solutions from scientists and community to improve environmental quality as well as to keep natural resources sustainable.

\section{State of the environment quality}

\subsection{Industrial and agricultural production}

The human's activities including the exploitation of fossils for industrial and agricultural production and trans- 
portation increased greenhouse gas emission. The agricultural sector is the main source that emits $\mathrm{CH}_{4}$ and $\mathrm{N}_{2} \mathrm{O}$, accounting for $75-80 \%$ of the total. Whereas, the energy sector is the main source that emit $\mathrm{CO}_{2}$, accounting for $70 \%$ of the total (MONRE, 2010). The emission of these greenhouse gasses is one of the factors causing the global climate change, in which Vietnam is one of the countries being strong affected.

The overuse of pesticides in epidemic prevention in $\mathrm{Vi}$ etnam has led to many cases of food poisoning, reduction in food safety and hygiene as well as polluted fields. Beside, construction and production activities caused soil erosion, consolidated soil and broken soil structure. The operation of manufacturing industries discharged the solid, liquid and gaseous waste affecting the soil (MONRE, 2010).

\subsection{Traditional craft villages}

Vietnam has more than 2100 traditional craft villages using more than 11 million labours (MONRE, 2010). They are located mainly in the densely populated lowlands, especially in the Red River Delta. These craft villages are of great significance in promoting socioeconomic development in rural areas. However, the level of production technology is low and backward, and people's awareness of environmental protection is weak. These features made the craft village become the cause of significant environmental pollution.

One of the typical examples of the environmental pollution caused by the activities of the traditional craft village is the Dong Mai village, Chi Dao commune, Van Lam district, Hung Yen province, Vietnam. Since 1978, the traditional village Dong Mai has developed professional lead recycling that was performed by households themselves at their houses and gardens. Nowadays the quality of soil, water and air around this traditional village still faces up to the problem of pollution by heavy metals especially lead $(\mathrm{Pb})$. In the garden soil of lead-recycling households, concentrations of $\mathrm{Pb}$ ranged from 7,000 to $15,000 \mathrm{mg} \cdot \mathrm{kg}^{-1}$ dry weight (DW). In paddy soil, contents of $\mathrm{Pb}$ were higher than the allowed values given by Vietnam standard (2002) from 3.6 to 100 fold (Chu, 2011). Lead pollution from lead recycling operations in the village Dong Mai has led to levels of lead in the blood of nearly one fifth of the local children examined in the year 2012 exceeded allowance limitation many times (24 out of 109 children examined) (DONRE, 2013).

Pollution of organic matter is also a matter of concern in Vietnam. For example, in starch processing villages in Hoai Duc district, Hanoi, the amount of solid waste discharged was from 56,000 to 82,600 tonnes annually calculated from the year 2000 to 2010. Besides, the wastewater was polluted seriously with high concentrations of $\mathrm{SS}, \mathrm{BOD}_{5}, \mathrm{COD}$, and coliform total number (Nguyen and Chu, 2012).

Environmental quality monitoring is essential topics in order to propose suitable solutions in time when contami- nation occurs. The studies on environmental pollution treatment are not focused and usually with small scale in Vietnam. Environmental pollution of air and water can be monitored and managed effectively by the application of GIS (Ngo et al., 2012). However, the study and practical application of large scale are very necessary to meet the needs of the whole nation on the issue of environment monitoring and management.

\subsection{Mining activities and energy supply}

Vietnam has total coal reserves reaching 5.8 billion tons, the total reserves of oil and gas is 1.4-1.5 billion tonnes of condensate and 2.4-2.7 trillion $\mathrm{m}^{3}$ of natural gas (Nguyen, 2007). Exploitation and use of coal in energy supply contain the potential risk if there are no suitable measures for treatment of wastewater and emission gas. Meanwhile, there are still no separate planning schemes and policies to encourage development of resources and potential for development of renewable energy that is considered to have low impact and almost no pollution to the environment (MONRE, 2010).

Activities in the metals mining sector in Vietnam like at the zinc-lead mining and processing factory in Tan Long commune, Dong Hy district, Thai Nguyen province, Vietnam also cause seriously environmental pollution. Lead and cadmium concentrations in the paddy soil near this factory varied from 1,271 to $3,953 \mathrm{mg} \cdot \mathrm{kg}^{-1}$ (DW) and from 2.3 to $42.9 \mathrm{mg} \cdot \mathrm{kg}^{-1}$ (DW), respectively. These values were higher than the allowance limit (Vietnam standard, 2002) from 18.1 to 56.5 and from 1.15 to 21.5 fold, respectively (Chu, 2011).

\section{Natural resources}

\subsection{Water resources}

Although Vietnam has sufficient amount of total water, the impact of climate change, uneven water resources distribution geographically and seasonally together with limited water supply facilities technology as well as inappropriate water resources management have resulted in water shortages in many areas (MONRE, 2010). Currently, total reserves of groundwater in Vietnam reach about 20 million $\mathrm{m}^{3}$. Meanwhile, groundwater in some areas of Vietnam is facing saline intrusion as well as serious pollution by heavy metal and microorganism as a result of impact of sea level rise and lack of protection of water resources.

The impacts of sea level rise on the water bodies of $\mathrm{Vi}$ etnam were also shown as changes in hydrology and chemistry of near coastal wetlands and aquatic ponds. This situation threatens much of the water used for irrigation and drinking purposes (Jeremy Carew-Reid, 2008).

Vietnam has a total water volume per capita approximately $9,560 \mathrm{~m}^{3} /$ person / year, lower than the standard of $10,000 \mathrm{~m}^{3} /$ person / year for national having water resources at average level in view of IWRA. In addition, water resources in river basins in Vietnam are 
being severely degraded and depleted due to increased water demand in many fields and due to weak management (MONRE, 2012).

\subsection{Biological resources}

Vietnam was recognized by the World Wildlife Fund (WWF) as having three out of more than 200 biological zones of the world. The International Union for conservation of Nature (IUCN) also recognized 6 biodiversity centers for flora in Vietnam. However, the number of endangered species listed in the Vietnam Red Book and IUCN's Red List is increasing. This alarming issue really needs considerable attention (MONRE, 2010).

Droughts occurred frequently on a large scale in dry seasons in the last decade, which forced people to evacuate land areas (MONRE, 2010). Moreover, it kills thousands of animals due to thirst and hunger, and dries up hundreds of ha of forests and plants that lead to forest fires.

In the year 2010, the total forest area burnt and destroyed in Vietnam reached to 7781 hectares, including 1058 hectares of forests destroyed (MONRE, 2010). This caused the high pressure on the natural environment of Vietnam when forest ecosystems play an important role in absorbing and storing $\mathrm{CO}_{2}$ in nature.

Climate change and sea level rise impact on forest resources in Vietnam in which, forest cover and other natural vegetation including shrub and grassland in Mekong River Delta are affected more heavily than those in other regions (Jeremy Carew-Reid, 2008).

\section{DAAD alumni workshop on "Sustainable Management of Environment and Natural Resources in Vietnam"}

The present DAAD alumni workshop on "Sustainable Management of Environment and Natural Resources in Vietnam" is funded by German Academic Exchange Service - DAAD (Germany) and Vietnam Academy of Science and Technology - VAST (Vietnam), and is organised by the Institute of Ecology and Biological Resources - IEBR (Hanoi, Vietnam). The workshop includes papers and presentations of biological, environmental scientists as well as the experts belonging to other related disciplines. The target of the workshop is to provide part- ly an overview of state-of-the-art status of environment and natural resources in Vietnam. The workshop is also expected to contribute to improve environment quality as well as sustainable management and exploitation of natural resources through innovation solutions proposed and experiences shared.

\section{References}

[1] Chu, T.T.H. 2011. Survey on heavy metals contaminated soils in Thai Nguyen and Hung Yen provinces in Northern Vietnam. J. Viet. Env. 1(1): 34-39.

[2] DONRE-Department of Natural Resources and Environment, Hung Yen province, Vietnam (2013) http://new.hungyen.gov.vn/vivn/stnmt/Pages/Article.aspx?ChannelId=18\&articleI $\mathrm{D}=590$, retrieved on 15 Nov. 2013. (In Vietnamese)

[3] Jeremy Carew-Reid 2008. Rapid assessment of the extent and impact of sea level rise in Viet Nam, Climate Change Discussion Paper 1, ICEM - International Centre for Environmental Management, Brisbane, Australia, 74pp.

[4] MONRE-Ministry of Natural Resources and Environment 2010. National state of environment 2010An overview of Vietnam environment, 199pp.

[5] MONRE-Ministry of Natural Resources and Environment 2012. National state of environment 2012Surface water, $117 \mathrm{pp}$.

[6] Ngo, T.B., Nguyen, T.A., Vu, N.Q., Chu, T.T.H., Cao, M.Q. 2012. Management and monitoring of air and water pollution by using GIS technology. J. Viet. Env. 3 (1): 50-54.

[7] Nguyen, P.H. and Chu, T.T.H. 2012. Investigation of the pollution status and the waste reusing ability in trade village Duong Lieu, Hoai Duc, Hanoi. J. Viet. Env. 3(2): 87-91.

[8] Nguyen, T.D. 2007. Decision 1855/2007/QĐ-TTg dated December $27^{\text {th }}, 2007$ approving the national energy development strategy towards 2020 , with a vision to 2050.

[9] Vietnam standard 7209:2002. Soil qualityMaximum allowance limits of heavy metals in the soil. 